\title{
Life as a UN Special Rapporteur: The Role of UN Special Rapporteurs in Developing International Law, the Impact of Their Work, and Some Reflections of the UN Special Rapporteur for Human Rights in Cambodia
}

\author{
Surya P. Subedi, $Q C^{\prime}$
}

\section{INTRODUCTION}

I am standing here today to deliver a public lecture of this nature since my first inaugural public lecture 10 years ago in May 2005 as the first Professor of International Law ever appointed at Leeds University. It remains the last inaugural public lecture delivered by any professor in this Law School thus far.' Today, I am proposing to examine the role of UN Special Rapporteurs in developing international law and the impact of their work with some reflections of my own.

I hope you will forgive me if it sounds like a 'swan song' at some points, but this lecture is partly an account of the work that I have been proud and privileged to do in Cambodia as the UN Special Rapporteur for the last six years. The idea of giving this public lecture was suggested to me by colleagues and doctoral students familiar with my work. The title of this lecture is 'Life as a UN Special Rapporteur'. I will talk about my experi-

1 Of the Board of Editors (1997-2006); LL.B. (Tribhuvan); LL.M. with Distinction (Hull); D.Phil. (Oxford); Barrister of the Middle Temple (London); O.B.E.; QC (Hon), UK; Professor of International Law at the School of Law of the University of Leeds; Former United Nations Special Rapporteur for Human Rights in Cambodia. This article is based on a public lecture that the author delivered at the University of Leeds on 5 May 2015. 
ence - with both challenges and achievements. It is basically a first-hand account of the interplay between law, politics and diplomacy.

My UN appointment came to an end on April 30, 2015 after working hard for six long years. I left the job with a mixed feeling of both relief and sadness. I enjoyed it, and I am satisfied with the progress the country has made during my tenure. It was an interesting but demanding position, especially while trying to juggle it with a full-time position at the University.

Before I proceed, I would like to take this opportunity to thank a number of people who have enabled me to carry out my duties for the UN to the best of my abilities. Among them are Professor Halson and Professor McCormack who were Head of School and Director of Research respectively at this Law School when I was appointed by the UN, and Professor Mullis, the current Head of Law School, after he joined Leeds. Others include my colleagues, Dr. Amrita Mukherjee, Chloe Wallace, Amanda Hemingway, and Tracey Rogers. I thank them for their understanding and assistance.

Within the UN system, my sincere thanks go to a number of people, both national and international staff at the Office of the High Commissioner for Human Rights, both in Phnom Penh and Geneva, who have assisted me and especially Christophe Peschoux, Wan-Hea Lee, Rory Mungoven, James Heenan, Olga Nakajo, Maureen Teo, Jung Rin Kim, and Robert Vaughan.

\section{THE ROLE OF THE UN SPECIAL RAPPORTEURS FOR HUMAN RIGHTS}

The main function of the UN Special Rapporteurs for human rights is to monitor the situation of human rights in a certain country and report publicly to the UN. It is about holding governments accountable for violations of human rights by asking sensible and often difficult questions to probe into the situation. In common parlance, it is about poking your nose into the 'internal' affairs of a State. Therefore, Special Rapporteurs are rarely welcomed with any degree of enthusiasm in any country, but they have to work with the government of a given country to have their recommendations implemented - a difficult balancing act in itself. The endeavour is to induce governments towards compliance with their international human rights obligations flowing from the treaties ratified by the country and to 
assist them to travel along the road to a stronger democracy, genuine rule of law and greater respect for human rights and to building their capacity to achieve this. ${ }^{2}$

Special Rapporteurs for human rights come in two different forms: thematic and country-specific mandate holders. The thematic mandate holders focus on a narrow human rights theme, but have a global mandate. The country-specific mandate holders are responsible for only one country, but cover the whole range of human rights issues within the country that can range from civil and political rights to economic, social, and cultural rights. ${ }^{3}$ One day you are dealing with issues relating to freedom of speech and the next day dealing with land rights or LGBTI rights, etc. There are only 12 of us in the world who are country-specific mandate holders and they are for some of the most challenging countries in terms of the protection of human rights. Examples are Cambodia, North Korea, Myanmar, Iran, Syria, Somalia, and Sudan.

The institution of Special Rapporteurs for human rights, known as special procedures, is one of the main mechanisms employed by the UN to protect and promote human rights worldwide. The Office of the UN High Commissioner for Human Rights describes this as "the most directly accessible mechanism of the international human rights machinery." The

2 See generally Philip Alston, Hobbling the Monitors: Should U.N. Human Rights Monitors be Accountable?, 52 Harvard International Law Journal 561, 563-649 (2011); David Weissbrodt, The Three 'Theme' Special Rapporteurs of the UN Commission on Human Rights, 80 American Journal of International LAw 684, 685-699 (1986); Helena M. Cook, The Role of the Special Procedures in the Protection of Human Rights: The Way Forward After Vienna, 50 Review of the International Commission of Jurists 31 (1993); Marc J. Bossuyt, The Development of Special Procedures of the United Nations Commission on Human Rights, 6 Human Rights Law Journal 179 (1985); Surya P. Subedi, Protecting Human Rights Through the Mechanism of UN Special Rapporteurs, 33 Human Rights Quarterly 201 (2011).

3 Special Procedures of the Human Rights Council, U.N. HUM. RTS. OFF. HIGH COMM'R, http://www.ohchr.org/EN/HRBodies/SP/Pages/Introduction.aspx (last visited May 15, 2016).

4 Office of the U.N. High Comm'r for Human Rights, United Nations Special Procedures: Facts and Figures 2009, http://www.ohchr.org/Documents/HRBodies/ SP/factsfigures2009EN.pdf (last visited May 15, 2016). 
UN Special Rapporteurs have long played an important role in promoting and protecting human rights in some of the most at-risk countries, such as those ruled by oppressive regimes and those that face some of the most challenging human rights issues of our times. The institution of rapporteurs has been in existence in some form since the late 1960 s. ${ }^{5}$ Various Special Rapporteurs have been appointed since then incrementally and on an ad hoc basis by various agencies within the UN system, mainly by the Human Rights Commission until 2006, and since then by the Human Rights Council. ${ }^{6}$

When the international human rights standard-setting process reached a certain height with the adoption of a number of international instruments, the UN program of human rights began to move to the next phase of development characterized by initiatives to implement through reporting, monitoring, and enforcement, the norms enunciated in such instruments. Accordingly, in spite of the principle of non-interference in the internal affairs of States embodied in Article 2(7) of the Charter of the United Nations, ${ }^{7}$ the UN began a process to examine the respective internal situations of human rights in individual countries and to report publicly the findings of investigations. The appointment of Special Rapporteurs with investigative and related powers was one of the mechanisms developed for this purpose. ${ }^{8}$ They are independent UN experts 'on a mission' whose primary task is fact-finding and reporting to the UN. ${ }^{9}$

Thus, the appointment of Special Rapporteurs was, as stated by Buergenthal, an attempt by the UN "to pierce the veil of [the] national sovereignty" of States to handle serious cases of human rights violations. ${ }^{10}$ This may be one reason why Kofi Annan, the former Secretary-General of the

5 U.N. GAOR, 13th Sess., I 24, U.N. Doc. A/HRC/13/39 (Feb. 9, 2010).

6 U.N. GAOR, 59th Sess., 56th plen. mtg. at 291, U.N. Doc. A/59/565 (2004); U.N. Secretary-General, In Larger Freedom: Towards Development, Security and Human Rights for All, gg 181-183, U.N. Doc. A/59/2005 (May 26, 2005).

7 U.N. Charter art. 2, 7.

8 Economic and Social Council Res. 2000/109 (May 27, 1970).

9 Ingrid Nifosi, The UN Special Procedures in the Field of Human Rights 1 (2005).

10 Thomas Buergenthal, New Customary Law: Taking Human Rights Seriously?, 87 American Society International Law Proceedings 229, 231 (1993). 
UN, described the institution of UN Special Rapporteurs for human rights as the "crown jewel" of the UN human rights machinery. ${ }^{11}$

In practice, the Special Rapporteurs perform a supervisory, consultative, advisory, or monitoring function, rather than one of enforcement. They are a special UN mechanism of a quasi-judicial nature. Hence, the name itself is "special procedures," and they are described in common parlance as the UN human rights envoys in many countries around the globe, especially by the media, or as the UN experts within the UN system itself. Indeed, it is an extraordinary mechanism based on the Charter of the United Nations and not on any particular human rights treaty.

The Special Rapporteurs have been crucial in promoting and protecting human rights through not only monitoring and fact-finding, but also standard-setting. They have significantly influenced the elaboration, interpretation, and implementation of international human rights law and have brought the human rights work of the UN to ordinary men and women around the globe. The institution of Special Rapporteurs is indeed a vibrant, autonomous, and flexible mechanism and their work can produce speedy and tangible benefits for the victims of human rights violations and can attract attention to such violations in both the national and international media.

In discharging their responsibilities, Special Rapporteurs receive information on specific allegations of human rights violations and send urgent appeals or letters of those allegations to governments to ask for clarifications. Another major feature of their activity is country visits, which help them investigate the situation of human rights of each country at a ground level. The Special Rapporteurs, especially those holding country mandates, face a huge challenge in meeting the expectations of the populations living under repressive regimes. Moreover, the UN system itself has high expectations from the rapporteurs, and their mandates are

11 Annan Calls on Human Rights Council to Strive for Unity, Avoid Familiar Fault Lines, U.N. News CTr. (Nov. 29, 2006), http://www.un.org/apps/news/story. asp?NewsID=20770. 
formidable. The following six different functions are combined into one package of the functions of Special Rapporteurs:

1. Analyze the relevant thematic issue or country situation, including undertaking on-site missions;

2. Advise on the measures which should be taken by the Government(s) concerned and other relevant actors;

3. Alert United Nations organs and agencies; in particular, the $\mathrm{Hu}-$ man Rights Council, and the international community in general to the need to address specific situations and issues (In this regard, they have a role in providing "early warning" and encouraging preventive measures);

4. Advocate on behalf of the victims of violations through measures, such as requesting urgent action by relevant States and calling upon Governments to respond to specific allegations of human rights violations and provide redress; and

4. Activate and mobilize the international and national communities, and the HRC to address particular human rights issues and to encourage cooperation among Governments, civil society and inter-governmental organizations and follow-up to recommendations. $^{12}$

Thus, a Special Rapporteur is expected simultaneously to become a human rights activist, a rallying point for human rights, an international diplomat, an academic, and a government advisor. Special Rapporteurs are selected on the basis of their personal integrity, independence, impartiality, objectivity, expertise, and experience in the area of the mandate. ${ }^{13}$ The key to performing their duties effectively depends on their independent

12 Olivier De Schutter, International Human Rights Law: Cases, Material, COMMENTARY 964 (2014).

13 Nomination, Selection and Appointment of Mandate Holders, U.N. HUM. RTS. OFF. HIGH COMM'R, http://www.ohchr.org/EN/HRBodies/SP/Pages/ Nominations.aspx. 
status and their ability to command respect from different stakeholders in a given society.

A Consultative Group of the Human Rights Council, comprised of five ambassadors to the UN nominated by each regional group of States, draws up a short list of candidates from the nominations or applications received and submit it to the President of the Council who makes a decision to appoint a Special Rapporteur. The President's decision has to be approved by the Council. ${ }^{14}$ While country specific Special Rapporteurs are normally appointed for one year at a time, the thematic mandate holders are appointed for a term of three years, renewable for a further term of three years. ${ }^{15}$ Special Rapporteurs are high-ranking UN officials who are regarded as being on par with the position of the Assistant Secretary-General of the United Nations for internal practical and logistical purposes. They enjoy certain functional diplomatic immunities and privileges because they are legally classified as "experts on mission" for the purposes of the Convention. ${ }^{16}$

\section{THE IMPACT OF THE WORK OF SPECIAL RAPPORTEURS}

There are of course critics who doubt whether the institution of Special Rapporteurs actually produces any tangible results for the victims of human rights violations. Indeed, in the absence of an effective followup system, many recommendations of the Special Rapporteurs remain unimplemented. However, the effectiveness of Special Rapporteurs may vary from one situation to another and from one Special Rapporteur to another, depending on the approach they adopt for the implementation of their mandates, the level of expertise and experience that they possess, and the approach that they adopt in implementing their mandate. The overall impact of their work, though, seems to significantly impact the enjoyment of human rights by people around the globe and especially those living under oppressive regimes. Just the fact that someone is watching over their activities makes governments think twice before taking measures against their own citizens. It is harder for governments to violate the human rights

\footnotetext{
$14 \quad I d$.

15 Human Rights Council Res. 5/1, U.N. Doc. A/60/251, at 45 (June 18, 2007).

16 U.N. Convention on the Privileges and Immunities art. 6, Feb. 14 1946, 1 U.N.T.S. 15 (entered into force Sept. 17, 1946).
} 
of their populations under the watchful eyes of the Special Rapporteurs. This is especially true for countries with a country mandate holder.

The fact that States do not respond formally to the communications by special procedures mandate-holders does not necessarily mean that the communications have no impact. In some cases, the very fact that matters under consideration have been brought to international attention can deter governments from taking questionable actions and galvanize them into positive action. Furthermore, the effectiveness of the work of the special procedures cannot be measured by the rate of response alone. It is the quality of the response that matters. A state may respond, but the response may be no more than a formality.

The effectiveness of the special procedures should thus be measured against the overall impact of their work on the Government, on the victims of human rights violations, the position taken by local human rights organizations, and so on. Even if there is no visible or tangible immediate impact of the work of the Special Rapporteurs, the long-term impact of human rights education and awareness of their work on the population in general in a given country and on the civil society organisations, human rights defenders and the youth in particular cannot be underestimated. Further, effectiveness of the work of Special Rapporteurs should be judged against their mandate and the powers that they have.

\section{THE UN MANDATE IN CAMBODIA}

The UN human rights mandate in Cambodia is one of the oldest and strongest. However, the nature of the mandate has changed over the years, and I saw it as more of a mandate to assist the Government with the management of transition rather than finger pointing. As a country which has gone through nearly 30 years of conflict, Cambodia has its own challenges in moving forward. "The new UN human rights envoy is welcome to Cambodia, but I hope he will not be as ignorant as his predecessor"17:

17 Cheang Sokha \& Georgia Wilkins, U.N. Envoy Welcomed, Warned, Рнном Penh Post, June 17, 2009, http://www.phnompenhpost.com/national/un-envoywelcomed-warned. 
these were the words in the headlines of The Phnom Penh Post ${ }^{18}$ reported to be from Prime Minister Hun Sen that greeted me upon my arrival in Cambodia on my first mission to the country in June 2009. The relations between the successive UN Special Rapporteurs and the Government of Cambodia had been controversial since the creation of the UN mandate for the country in 1993. The work of the Special Rapporteurs in Cambodia has been a rollercoaster journey for each of the mandate holders since then, and my experience is no different.

\section{a. A Tragic Past}

Cambodia is a country still coming into terms with a tragic past of nearly 30 years of conflict created by both internal and external factors. The trials of some of the Khmer Rouge rulers before the hybrid court, which is a national court with international UN involvement, are still ongoing. The Tribunal has already convicted the head of detention and torture camp and two of the most senior leaders of the Pol Pot regime on charges of crimes against humanity.

While the country suffered from the rivalry and proxy war between the major international powers of the day, it also witnessed one of the most brutal regimes of the twentieth century - the Khmer Rouge between 1975 and 1979 - resulting in the huge loss of life and the destruction of the state apparatus. The legal, institutional, and political systems had to be rebuilt

18 See Paris Conference on Cambodian Agreements, Oct. 23, 1991, http://www. usip.org/publications/peace-agreements-cambodia; United Nations Transitional Authority in Cambodia, G.A. Res. 46/608, U.N. Doc. A/46/608-S/23317 (Oct. 30, 1991). The Paris Peace Accords of 1991 consist of the following main agreements concluded by 19 countries which included all major powers of the day, the neighbouring countries of Cambodia, some regional powers and other States which had a significant interest in Cambodia: The Agreement on a Comprehensive Political Settlement of the Cambodia Conflict; the Agreement concerning the sovereignty, independence, territorial integrity and inviolability, neutrality and national unity of Cambodia; Declaration on the Rehabilitation and Reconstruction of Cambodia; and Annexes 1 to 5 to the Paris Peace Accords. See: www.usip.org/ library/pa/cambodia/agree_comppol_10231991.html. 
effectively from scratch when the country began to pull itself together after the end of the Khmer Rouge rule in 1979.

The Paris Peace Accords concluded in 1991 paved the way for political reconciliation and the establishment of a democratic Cambodia. ${ }^{18}$ The United Nations Transitional Authority in Cambodia (UNTAC) created under the Paris Peace Accords led the transition. Consequently, Cambodia adopted the 1993 Constitution founded on the rule of law, respect for human rights, the independence of the judiciary, separation of powers, and the democratic governance of the country. ${ }^{19}$ However, Cambodia remains a complex country in terms of the protection and promotion of human rights, as democratisation has not yet fully taken root. The major areas of concern are those relating to access to land and housing rights, freedom of expression, and the numerous challenges faced by the judiciary. These issues continue to dominate the legal and political landscape.

\section{b. Bridge-building Act}

When I was appointed by the UN Human Rights Council as the UN Special Rapporteur for human rights in Cambodia in March 2009, relations between the previous UN Special Rapporteur and the Government had broken down and the country was heading towards greater authoritarian rule. My predecessor had virtually been declared a persona non grata ${ }^{20}$ by the Government and had difficulty visiting the country. According to the WikiLeaks reports, leaked under the direction of Julian Assange, an Australian Internet activist ${ }_{2}$ the American Ambassador to Cambodia, Carol Rodley, had stated in her sensitive/secret report to the State Department that my predecessor had effectively been banned from Cambodia in March

19 Constitution of the Kingdom of Cambodia, Wikisource, https://en.wikisource. org/wiki/Constitution_of_the_Kingdom_of_Cambodia (last modified Nov. 26, 2015).

20 Refers to foreign person whose entering or remaining in a particular country is prohibited. Persona Non Grata, Wikipedia, https://en.wikipedia.org/wiki/ Persona_non_grata (last modified May 12, 2016). 
2008. ${ }^{21}$ There were genuine fears that the country with its tragic past would witness violence yet again.

Given the tragic past of the country and confrontational relations between my predecessors and the Government, I had to tread a careful path when I was appointed. I started to build bridges and restore lines of communications with the Government by adopting a constructive approach, designed to bring about positive results by engaging the Government in reform and employing diplomatic skills to this effect. I billed my first mission as a 'listening tour' or a 'diplomatic mission.'

\section{c. Painting a Picture at a Bigger Canvass}

I took a macro rather than a micro approach to tackle human rights problems in Cambodia and gave constructive recommendations to the Government in this regard. My attempt was to paint a picture on a bigger canvass. In fact, this is an approach I take in life generally, whether it is in my academic writing or other activities in life. I have a habit of taking a macro approach to any task at hand, strategically looking at the broader picture, and grappling with the main issues of the day. I do not think that I am a man of details.

Perhaps, being a person born and brought up in a country with towering mountains, I have a natural tendency to see things further afield, on the wider horizon from a hilltop, rather than in the immediate periphery. Therefore, when I began my work in Cambodia, I believed it was important to grapple with the broader picture of the country and decided to examine the whole structure of governance that led to human rights violations rather than to examine myself to examine the situation of human rights in a narrow thematic area, such as freedom of speech, the rights of people with disability, and LGBTI rights. This does not mean that I neglected those issues. I included many of them in my annual reports, but the focus of my attention was improving the system of governance as a whole, with

21 For Human Rights in Cambodia, WikiLeaks, (June. 29, 2009, 10:54), https:// wikileaks.org/plusd/cables/09PHNOMPENH426_a.html. 
the hope that, by doing so, the overall situation of human rights in the country would improve.

\section{THE DEVELOPMENT OF DEMOCRACY IN CAMBODIA}

There was a liberal democratic constitution in Cambodia and national institutions that existed to protect the rights of the people. But, human rights violations were a daily occurrence and these national institutions have not been effective in protecting the rights of Cambodian citizens. I thought there was something fundamentally wrong at the heart of governance in Cambodia which led to human rights violations. Accordingly, I proposed to the Government that I would like to examine the effectiveness of the State's institutions responsible for upholding people's rights, such as the judiciary, parliament, national election committee, and national institutions, responsible for land management and resolution of land disputes. Whether the people in the Government understood my approach or not, they consented to it.

I began my work by assessing the whole political structure of the country, and I produced four substantive and substantial reports focusing on the judiciary, parliamentary, and electoral reform as well as on the impact of economic and land concessions on people's lives. Collectively, these four reports provided an analytical picture of democracy, human rights and the rule of law in the country and quickly became a primary source of reference for human rights defenders, UN agencies, donor agencies and the ordinary citizens.

\section{a. Enhancing the Independence of the Judiciary}

Not surprisingly, as a lawyer by both training and profession, I thought I should begin my work by examining the effectiveness of the judiciary in Cambodia in protecting people's rights. I examined the ability of the judiciary to deliver justice and to command the respect, trust, and confidence of the people. After conducting two fact-finding visits to Cambodia, focusing on its judiciary, I identified a number of shortcomings in in the functioning of the judiciary and made recommendations to address them. The purpose of this assessment was to identify the ways and means of strengthening their capacity to protect and promote human rights. After 
my two fact-finding missions, I realised that the reasons why the judiciary was not able to enjoy the reputation it should were manifold. While some of the roadblocks were attributable to the historical legacy of the Khmer Rouge period during which the judiciary was dismantled and judges and lawyers killed, there were a variety of other factors that contributed to it.

First, there was an absence of law on the status of judges and prosecutors that could have provided them with the protection, security of tenure, and independence that they needed to discharge their responsibilities in an effective and independent manner.

Second, the absence of the (subsequently created) "Law on the Organization and Functioning of the Courts" seemed to have a detrimental impact on the effectiveness and independence of the judiciary in impartially reaching justice in a timely manner. The law mentioned above was needed to achieve a degree of unity, cohesion, and certainty within the system of justice. The legal and judicial reform programme, part of the Government's "Rectangular Strategy," provided for the enactment of this law, but it had not yet materialised.

Third, many judges and lawyers, particularly of the older generation, seemed to have no proper grounding in the fundamental principles of the rule of law and international legal standards, which are generally expected of a judge. There were relatively few eminent senior jurists in the country. Inadequate legal education or training of judges and prosecutors on the fundamental principles of natural justice, the rule of law, and international standards of fair trial seemed to have contributed to making the judiciary a weak institution in the structure of governance.

Fourth, much of the population seemed generally fearful of courts, partly due to corruption and partly due to the manner in which the court system operated. There were not enough defence lawyers in criminal cases, and the conviction rate was very high. In a significant proportion of cases, the accused were convicted by courts on the basis of their confessions extracted while in police custody, and often while under duress. There were a large number of poor people involved in land disputes, but since they were civil cases, there were no provisions providing legal aid from the State for the poor. There were not enough women police to investigate crimes against women. There were no provisions that provided any proper training in forensic science for the judicial police, prosecutors, or investigating 
judges. Because there was no clear differentiation between the prosecutors and judges, Cambodians had difficulty in understanding their roles.

Fifth, corruption seemed to be widespread at all levels in the judiciary. Because no laws needed to protect the judges were in place, the judges were treated as civil servants and seemed to rely on patronage and political protection rather than on the law for the security of their jobs. This had resulted in individual judges' and prosecutors' compromising their independence.

Sixth, judicial proceedings were being used by the rich and powerful in many cases to dispossess, harass, and intimidate the poor as well as their own lawyers and those working for them in the civil society sector.

Seventh, the lack of human, budgetary, and physical infrastructurerelated resources seemed to be seriously hindering the work of the judiciary. The judiciary in Cambodia was chronically underfunded, under-resourced, and understaffed. Prosecutors had insufficient funds to order proper scientific investigation of crimes. Hence, the tendency was to rely on confessions extracted from the accused by the judicial police. The judicial police themselves were not properly trained in criminal investigations, and frequently used constraint or force to obtain confessions of guilt.

Eighth, the ratio of lawyers and judges per head of the population in Cambodia was very low. This was particularly of concern in a system where, without lawyers, one cannot have access to court files. What is more, most judgments were treated as confidential. There was only one Court of Appeal in Phnom Penh and the poor could not afford to travel to the capital city for justice. Even the State machinery did not seem to have an adequate budget to transfer inmates to Phnom Penh for their appeal hearings. As a result, many appeal hearings took place without the presence of the accused or even their lawyers.

Ninth, although the Constitution of Cambodia provided for the separation of powers between the three main organs of State, in practice, the distinction between these organs was blurry; the executive branch dominated the judiciary whether by providing resources to the judiciary or in making appointments to various judicial positions. This remained a key challenge for the country in implementing the rule of law and in promoting and protecting people's rights.

On the basis of the above analysis, I wrote a report on enhancing the independence and capacity of the judiciary and made a series of recommendations to the Government including enacting three different sets of 
laws to this effect. I recommended that two news laws, namely the "Law on the Status of Judges and Prosecutors" and the "Law on the Organization and Functioning of the Courts," should be enacted, while the "Law on the Organization and Functioning of the Supreme Council of Magistracy" should be amended. ${ }^{22}$

\section{b. Parliamentary Reform}

After examining the judiciary, I turned my attention to Parliament, which had been operating basically as a rubber-stamp institution subservient to the all-powerful executive. The Cambodian Parliament faced the same institutional and structural upheavals that the country as a whole faced in the preceding 40 or so years. Like the judiciary, Parliament and parliamentary culture had to be rebuilt from scratch, following the systematic destruction of all democratic institutions during the Khmer Rouge period. After conducting two further fact-finding missions, I identified a number of shortcomings in the workings of Parliament in general and the National Assembly in particular.

Many bills were being rushed through the Assembly without a proper debate. The tightly controlled system of adopting laws in the Assembly had meant, in practice, that amendments were rarely accepted at any stage of the process. This highlighted the limited effectiveness of the Assembly in scrutinizing legislation prepared by the executive. Furthermore, a number of pieces of legislation adopted had tended to narrow the scope of human rights. Overall, the ability of Parliament in Cambodia to restrain this executive tendency had been limited.

A key obstacle was the lack of a properly functioning parliamentary culture. The notions of pluralism and liberalism enshrined in the Constitution were designed to ensure space for all to participate in the process of democratization and nation building. However, there was an absence of a culture of debate and discussion, as well as political will to foster a climate that was conducive to constructive dialogue and acceleration of the process of democratization of Cambodian society.

In my opinion, parliament is the soul of democracy. For democracy to work properly, all individual members of parliament should be able to

22 Surya Subedi, Special Rapporteur on the Situation of Human Rights in Cambodia, U.N. Doc. A/HRC/15/46 (Sept. 14, 2010). 
exercise their freedom of speech in the course of discharging their official duties. It is a fundamental condition for a member of parliament to be able to speak his or her mind without fear. Democracy is about dialogue and debate on all issues of national importance, and this is especially so in the case of a parliament, which by definition is a chamber where members can debate freely any issues of national importance. ${ }^{23}$ It is for this reason that they have been accorded parliamentary immunity.

However, some of the internal rules of procedure of the National Assembly were not conducive to enabling all individual members to enjoy their freedom of speech when holding the executive to account and defending the rights of the people that they represent. The scope for Members of Parliament in Cambodia to participate in parliamentary debate had been limited and the parliamentary immunity of a number of Members of Parliament had been lifted, even for speaking out on issues of national importance. Further, many of these members had not been given an opportunity to make a representation in their defence, which goes against the basic principles of natural justice.

A properly functioning democracy requires effective checks on the executive and on the majority. However, some of the provisions of the Law on the Status of National Assembly Members seemed to go beyond the freedom of speech guaranteed to members through the Constitution.

Ministers rarely attended the meetings in Parliament to answer questions from Members of Parliament. The Members of Parliament belonging to the main party in opposition and some other minority parties were virtually cut off from the law-making process. The Cambodian People's Party, with its large majority in the National Assembly, had a tendency to ignore the political role of other parties. The opposition party and many other minority parties complained that they were treated by the ruling party as an enemy of the State rather than as political partners with differing views. Although the Constitution required a secret ballot for important decisions in Parliament, most important decisions in the National Assembly were taken on the basis of bloc voting and by show of hands so that the Government could identify the people voting against any of its motions. 
The individual members of Parliament seemed therefore to lack the courage to vote independently or against proposals tabled by the Government.

An individual Member of Parliament was not able to speak in Parliament without going through a group leader and without getting the permission to do so from the President of the National Assembly. These rules had the effect of denying Members of Parliament belonging to minority parties with fewer than 10 seats any meaningful role in Parliament. For the reasons outlined above, the role of Parliament had been limited to overseeing the work of the executive. With this in mind, I made a series of recommendations for parliamentary reform designed to enable members of parliament to hold the executive to account for violations of human rights and to protect the rights of the electorate. ${ }^{24}$

\section{c. Electoral Reform}

After my work on parliamentary reform, the focus of my activity was on electoral reform. This is because free and fair elections underpin respect for international human rights norms. Indeed, Article 25 of the International Covenant on Civil and Political Rights (to which Cambodia is a State party) provides that everyone has the right to take part in the conduct of public affairs in the country, and to vote (and to be elected) "at genuine periodic elections which shall be by universal and equal suffrage and shall be held by secret ballot, guaranteeing the free expression of the will of the electors." 25

The Constitution of Cambodia firmly establishes the country as a liberal democracy, and elections are central to democracy. ${ }^{26}$ During my fact-finding missions, I received a large amount of information from people and institutions, including allegations of irregularities or systemic problems that undermined the country's ability to hold free and fair elections. I carried out my own independent assessment of the situation. I argued that reforms should be carried out to ensure that elections in Cambodia are free and fair and that Cambodians can exercise their right to democratic governance in a free political environment. I stated that free and fair elections could take place only when there is a free political environment and

24 U.N. GAOR, 18th Sess., 33d plen. mtg., U.N. Doc. A/HRC/18/46 (Aug. 2, 2011).

25 International Covenant on Civil and Political Rights art. 25, opened for signature Dec. 16, 1966, 6 U.S.T. 3518, 999 U.N.T.S. 171.

26 U.N. GAOR, 21st Sess., 32d mtg. at 4, U.N. Doc. A/HRC/21/63 (July 3, 2012). 
the people are able to exercise their rights and freedoms, such as freedom of expression and assembly, as well as the freedom to stand for election. To hold credible elections, the Government must ensure high standards in line with its international human rights obligations before, during, and after the casting of votes. It must also ensure the independence of the National Election Committee.

There were major flaws in the administration of elections in Cambodia and urgent and longer-term reforms were needed to give Cambodians confidence in the electoral process and in the workings of the National Election Committee. Accordingly, I made a series of recommendations for electoral reform. The main one was to grant constitutional, independent, and autonomous status to the National Election Committee. My key recommendations were as follows:

1. The National Election Committee should have independent and autonomous status in the constitutional and legal structure of Cambodia, with its own independent budget allocated by the Parliament. The President and members of the Committee should be drawn from a pool of retired senior judges, senior and distinguished members of the Cambodian bar and senior professors of law, politics and public administration.

2. There should be consensus among the major political parties represented in the Parliament on the appointment of the president and members of the National Election Committee and the provincial election committees.

3. The President and members of the National Election Committee and the provincial election committees should be appointed for a fixed term and have security of tenure. They should be barred from holding positions in political parties during and up to two years after the expiry of their terms of office.

4. All major political parties should have fair and equal access to the mass media to convey their messages to the electorate.

5. The Government must ensure that all civil servants, police and military personnel do not participate in political activities or use 
Government resources while working in their official capacities, and that neutrality is paramount.

6. The leader of the opposition should be allowed to return to the country from his exile in France to participate in the political process in the country and this was crucial especially in the runup to the general elections. ${ }^{27}$

It was after I submitted my report on electoral reform with the above recommendations that I faced the wrath of the Government. Undeterred from my mission, I responded to the criticisms from the Prime Minister in a diplomatic and professional manner which seemed to then put the Prime Minister back from an aggressive position into a defensive one.

\section{d. Land Reform}

The issues associated with land and housing rights are rather unique in Cambodia. Most of the issues concerning land management and the evictions of people from land are the result of one of the most horrendous human tragedies of modern times, i.e., the movement of people in huge numbers from east to west and from north to south in search of sanctuary during the conflict in Cambodia. Millions were forced to leave the capital, and other cities and towns during the rule of the Khmer Rouge, while many other millions were traumatized by the conflict fled from their homes to save their lives. ${ }^{28}$ The situation was further complicated when the notion of the communal ownership of land was introduced during the period between 1979 and 1989. ${ }^{29}$

When relative peace returned to Cambodia, people from the countryside began to return to their homes and land, and those who had gone abroad to seek refuge also began to come back. However, many had lost evidence proving their ownership of such property. During the rule by the Khmer Rouge, nobody was allowed to own anything. Official records were systematically destroyed, and lawyers and surveyors were killed, to make

$27 \quad$ Id. at 16.

28 Surya Subedi, The UN Human Rights Mandate in Cambodia: The Challenge of a Country in Transition and the Experience of the Special Rapporteur for the Country, 15 International Journal of Human Rights 249, 252 (2011).

29 See supra note 25 , at $8-9$. 
way for the so-called the "new society". Thus, the task of land management and land titling was, and is still, a mammoth one in the country.

However, the manner in which the authorities dealt with the urban poor, those on the margins of society, and the indigenous communities, had been haphazard. The Government had no proper national guidelines on land evictions. Although there seemed to be some politicisation of eviction issues and some of the problems may have been created by the so-called land-grabbers and land speculators, many of the evictions by the authorities had been rather heavy-handed, favouring the rich at the expense of the poor. Although the Government had gone to great lengths to protect the interests of the urban poor, it had not followed international human rights standards in evicting people from disputed land sites; nor had the Government followed the provisions of the 2001 Land Law in doing so. ${ }^{30}$ The Government was slow in distributing land titles to possible owners and quick in evicting them from sites designated for developmental purposes, regardless of whether they had possession rights under the law.

The issues associated with land rights disputes and evictions were the number one human rights issue in Cambodia so far as ordinary citizens were concerned, and it continued to dominate the headlines in the media in Cambodia. The manner in which land was managed and used by the Government for various purposes continued to be a major problem. Land-grabbing by those in positions of power was a common occurrence. Economic land concessions leased to companies and other land transactions had severe consequences for the rural and urban poor, as well as for indigenous people. For instance, in 2009 alone, at least 26 evictions displaced approximately 27,000 people in Cambodia. ${ }^{31}$

The 2001 Land Law did provide a legal framework to deal with issues of land ownership, but there have been problems in implementing this law properly. Therefore, during my mission in the country, delegations after delegations, both large and small that consisted of members from some of the most vulnerable sections of society, came to see me with their petitions

30 Land Law_010430, Council For Dev. Cambodia, CDC, http://www. cambodiainvestment.gov.kh/land-law_010430.html (last visited May 15, 2016).

31 Overall Status of Economic Land Concession in Cambodia, Ministry Agric., Forestry, ANd Fishery for Food Sec. and Sustainable Dev., http://www. elc.maff.gov.kh/index.php/news/8-overal-status-of-economic-land-concessionin-cambodia (last visited Apr. 24, 2016). 
urging me to intervene to protect their rights. The issues they raised related to land concessions, including forced evictions, poorly planned resettlement and relocation, environmental destruction, unsustainable exploitation of natural resources, and threats to indigenous peoples' livelihood, culture, and traditions, among others.

An increasing number of cases also came to my attention in which individuals and communities (claiming their rights to land), land activists, and other human rights defenders have been harassed, threatened or criminalized based on challenges to the granting and management of economic and other land concessions. It was against this backdrop that I decided to focus two of my missions on examining the situation of land and housing rights in general and the human rights impact of economic land concessions in particular.

The objective was to have a fresh look at the human rights challenges posed by land concessions in light of the rapid growth in the number of concessions granted to both national and foreign companies and the detrimental impact of such concessions on the lives of the people. On the basis of an extensive fact-finding mission which focussed on the human rights impact of economic land concessions I submitted a detailed report analysing the breadth, depth and gravity of the issues and included a series of recommendations to improve the situation.

I acknowledged that historical circumstances, including the policies of the Khmer Rouge regime and the widespread destruction and dislocation left in the wake of Cambodia's lengthy civil war, had led to the proliferation of land disputes that the Government was trying to manage. I also stated that Cambodia, as a developing country, might wish to prioritize utilization of its land and natural resources in order for the country to develop and become more prosperous. Nevertheless, I stated that land concessions should be granted and managed within a sound legal and policy framework, including due consideration for and consultation with those who are affected, and with the sustainable use of natural resources in mind.

I pointed out that the majority of the challenges I have identified in the report derived from a failure to apply the domestic legal framework that is, the laws, policies and regulations. Consequently, the granting and management of economic and other land concessions in Cambodia suffered 
from a lack of transparency and adherence to existing laws. Accordingly, my key recommendations to this effect were as follows:

1. The Government should be rigorous and transparent in granting and monitoring land concessions, especially when negotiating concession agreements with both foreign and national companies, avoiding conflicts of interest, and holding concession companies to account by exercising oversight over their activities and resolving land disputes.

2. The Government should make information available concerning land investment, land deals and bidding processes, review of proposals for land concessions and future plans publicly accessible.

3. The Government should make available information on the systematic mapping, classification and registration of state public and private land and create and maintain a state land database. Information on the allocation, management and reclassification of state land should be made available in accordance with the existing laws.

4. Companies of all sizes, structures and modes of operation, both domestic and foreign, and whether wholly or partly owned by the State, should add ress their human rights impact by practicing due diligence, including implementing measures to identify, prevent, and mitigate adverse human rights consequences and account for their business activities.

5. In the case of foreign-owned companies, the home States should ensure that representatives of private business enterprises under their jurisdiction do not contribute to adverse human rights impacts by regular monitoring and oversight.

6. Evictions and resettlement should only be used as a last resort, and a moratorium on forced evictions should be in place in relation to all concession activity. When due process has been followed and eviction has been deemed to be legal and in the public interest, affected families should be consulted on how and when the relocation will occur and all efforts made to ensure it is carried out under conditions that adhere to international human rights standards related to adequate housing and fair and just compensa- 
tion. Additional efforts should be made to reestablish livelihood opportunities.

7. In the case where a land concession has been granted on the land traditionally occupied and used by indigenous peoples, restitution should be provided and the land reinstated, with the opportunity for the communities to register as legal entities and apply for communal land title.

8. The court system should not be used as a mechanism to criminalize land activists, individuals making claims for their land, human rights defenders and local authorities. ${ }^{32}$

This report on the human rights impact of economic land concessions was welcomed by the development partners of Cambodia and civil society. After criticising me for some of the conclusions that I reached about the real benefits of the economic land concessions for the people of Cambodia, the Government started to appreciate the report on the whole and started implementing some of the recommendations that I had made.

\section{IMPACT OF MY WORK}

It is difficult to measure the impact of the work of any Special Rapporteur. This is because while some impact is visible and short-term, others are not easily visible and may have a longer-term impact. Furthermore, along with the Special Rapporteur, various other stakeholders would be working on any given human rights issue. Thus, any change in the Government's policy or any positive action generally would be the result of a collective endeavour. Having said this, the Government of Cambodia takes seriously what its Special Rapporteur does or says in public. Often, the response from the Government to any criticism of governmental policy is quick and is made through the media. On most occasions, the Prime Minister himself reacts to the work or comments of the Special Rapporteur; on other occasions it is the Foreign Minister ${ }^{33}$ or the spokesperson of the Ministry of Foreign

32 U.N. GAOR, 21st Sess., U.N. Doc. A/HRC/21/63/Add.1 (Sept. 24, 2012).

33 Hor Nam Hong: By Keeping UN in Cambodia, We Want Further Enhancement of Democracy and Human Rights, Kampuchea Thmey Daily Newspaper, Jan. 25-26, 2015. 
Affairs or of the Cabinet. It could also sometimes be another leading figure within the ruling political party - Cambodian People's Party (CPP) - who would express the views of the Cambodian Government.

Major powers and other international development partners, including human rights organisations and other sections of civil society, have referred to my work in formulating their own policies concerning Cambodia. ${ }^{34}$ For instance, according to the reports leaked by WikiLeaks, the American Ambassador to Cambodia, Carol Rodley, stated in her secret and sensitive report to the State Department assessing my work in the country that I was "off to a better start than could be expected" and she "was glad to see [my] optimism because it would be needed." 35 Both members of the Government and in the opposition have picked and chosen bits and pieces from my report for their own purposes. The media, too, have done the same, selecting those snippets from my reports and statements that fit into their news stories and to support their own perspectives. ${ }^{36}$

International organizations have also referred to my reports in their work on Cambodia. For instance, the Inter-Parliamentary Union (IPU) made a reference to my report to the Human Rights Council in expressing its own concern ${ }^{37}$ when the leader of the opposition in Cambodia was sentenced to 10 years' imprisonment on some politically motivated charges. The IPU went on to urge the Government of Cambodia to "heed the recommendations made by the United Nations Special Rapporteur on the situation of human rights in Cambodia." 38 Similarly, the World Bank froze new loans in 2011 to Cambodia when many other stakeholders and

34 Letter from Lady Catherine Ashton \& Karel de Gucht, Head of EU's Foreign Affairs Div. \& EU Trade Comm'r, to Members of Eur. Parliament (May 15, 2013) (on file with author).

35 For Human Rights in Cambodia, supra note 21.

36 Cambodia's Politics: The Vision Thing, Economist, July 19, 2014, http://www. economist.com/news/asia/21607876-opposition-does-not-know-what-do-exceptobstruct-vision-thing; David Pilling \& Michel Peel, Cambodia: Wave of Discontent, Financial Times, July 29, 2014, https://next.ft.com/content/b01c354e-13f2-11e48485-00144feabdc0; UN Envoy Rebukes Cambodia Over Shooting of Protesters, BBC, May 10, 2012, http://www.bbc.co.uk/news/world-asia-18015436.

37 Governing Council of the Inter-Parliamentary Union [IPU], 187th Sess., CMBD/01 (Oct. 6, 2010), http://www.ipu.org/hr-e/187/Cmbd01.htm.

Id. 
I highlighted the plight of the people who were forcibly evicted from their lands and homes in the Boeung Kak Lake located in the middle of the city of Phnom Penh to make way for foreign investors to commercially develop the area. It considered unfreezing the loans when the situation of human rights in the country improved, especially after a political deal was reached between the Government and the opposition party. ${ }^{39}$

\section{a. Policy Impact}

After I produced four substantial and substantive reports on judicial, parliamentary, and electoral reform and on the impact on human rights of economic and other land concessions in the country, I came under criticism from the Government. I had, in my reports, called for sweeping reforms to ensure the independence of the judiciary and free and fair elections in the country - this did not go down well with the Government. Government officials and others often asked why I was recommending the reform of institutions that were not broken. I was told that there was nothing wrong, for instance, with the National Election Committee. However, as the date of the Cambodian parliamentary elections drew closer in 2013, and when the elections took place, the veil was lifted and its weaknesses were exposed. I received widespread support both at the national and international level, including from President Obama, in my dealings with the Cambodian Government.

While making the first ever visit by a U.S. President to Cambodia in November 2012 to attend the U.S.-ASEAN summit meeting in Phnom Penh, President Barack Obama called Cambodia's lack of respect for fundamental freedoms an 'impediment' to deeper relations between the two countries, adding that countries that do not uphold certain universal principles, such as respect for human rights, will have more difficulty integrating with

39 World Bank Mulls Funds, Phnom Penh Post, Nov. 12, 2014, at 1; See also World Bank Promises Meetings Before Ending Funding Freeze, Cambodia Daily, Nov. 19,2014 , at 4 . 
the international community. ${ }^{40}$ Similarly, the European Parliament, ${ }^{41}$ the Inter-Parliamentary Union (an inter-governmental organisation of national parliaments of 162 countries), ${ }^{42}$ and the Senates of Australia ${ }^{43}$ and the Philippines ${ }^{44}$ passed resolutions calling on the Cambodian Government to implement my recommendations. It was a rare display of international support for my work which made the Government reconsider its position.

Nevertheless, the general elections in July 2013 went ahead without implementing my recommendations for electoral reform. Consequently, the opposition party refused to accept the results which had declared the ruling party the winner and started a campaign of protests which was gaining momentum and receiving widespread support. Alleging electoral irregularities in the July 2013 general election and challenging the independence of the National Election Committee, the opposition party members refused to take their oath of office to join parliament and took to the streets.

As soon as the world was preparing to welcome and celebrate the New Year 2014, the scale of demonstrations in Cambodia had increased resulting in violence. Five people were killed in clashes with the police and military police on the $4^{\text {th }}$ of January. As a result, I decided to issue a strong statement condemning the Government for using live ammunition against peaceful demonstrators. I had to act fast and issue the statement that very day to maximize its impact by putting the Government on notice and under the international spotlight. Thankfully, Cambodia being 7 to 8 hours ahead of us, I had the time to receive information, verify the facts, digest them and react immediately. National and international media picked up

40 Rapporteur Backed: Rights or a Rough Ride, Warns U.S., Phnom Penh Post, Dec. 14, 2012 (reporting that the U.S. State Department in a letter sent on behalf President Obama to a group of leading U.S. senators concerned about the situation of human rights in Cambodia stated that the U.S. had called on the Cambodian Government to heed the recommendations of Professor Subedi).

412014 O.J. (C 72) 6.

42 Governing Council of the Inter-Parliamentary Union [IPU], 191st Sess., CMBD/01 (Oct. 24, 2012), http://www.ipu.org/hr-e/191/cmbd01.htm.

43 Commonwealth, Senate Daily Summary, 29 Oct. 2012, 3152 (Austl.).

44 S. Res. 130, 15th Cong. (2012) (Phil.). 
my statement quickly. Soon after issuing this statement, I was heading to Cambodia on my fact-finding mission.

Concerned perhaps by the consequences of my visit for the people in power, I was informed that the Prime Minister together with more or less the entire cabinet would meet with me since the situation in the country was very grave indeed. When I reached Phnom Penh, large number of people took out a rally and came to see me with a petition. The opposition party requested me to act as a mediator to resolve the political deadlock in the country. ${ }^{45} \mathrm{I}$ had a meeting with the Prime Minister and most of his cabinet colleagues for three and a half hours in the main meeting hall of the Council of Ministers, where I boldly and strongly delivered my message and concerns to Prime Minister, Hun Sen, and his Cabinet colleagues.

I said what the Government had done did not meet the tests of proportionality, legality, and necessity and called for a thorough, credible, and independent investigation into the deaths of peaceful demonstrators. ${ }^{46} \mathrm{I}$ reiterated that unless and until there was a clear commitment to carry out the reforms that I had suggested, the country would be witnessing more violence. It was at that meeting that the Prime Minister agreed to many of my recommendations relating to the judicial, electoral, and other political reforms.

The Prime Minister asked me to convey his message of reconciliation to the leaders of the opposition which I did. Thus, much of the time spent during my visit to Cambodia was acting as some sort of an informal mediator ${ }^{47}$ to achieve political reconciliation, and I believe I achieved a great deal during this time. I felt vindicated and came back to Leeds satisfied. Working from England, I thought I had influenced the political course of history in Cambodia. The leaders of the ruling party and the opposition

45 Heng Reaksmey \& Sok Khemara, UN Envoy Says He Would Consider Mediating Political Talks, VOA СамвоDiA (Jan. 16, 2014), http://www.voacambodia.com/ content/un-envoy-says-he-would-consider-mediating-political-talks/1831431. html.

46 Lauren Crothers \& Khy Sovuthy, Subedi Calls for Accountability in Meeting With Hun Sen, Cambodia Daily (Jan. 16, 2014), https://www.cambodiadaily.com/ archives/subedi-calls-for-accountability-in-meeting-with-hun-sen-50675.

47 Heng Reaksmey, Hun Sen Asks UN Envoy To Mediate Political Talks, VOA Самвоdia (Jan. 16, 2014), http://www.voacambodia.com/content/hun-sen-asksun-envoy-to-mediate-poli/1830750.html. 
struck a deal on July 22, 2014 to end the political deadlock in the country, and the deal included a commitment to carry out the electoral reform that I had recommended. ${ }^{48}$ The leader of the opposition in Cambodia wrote to me on August 6, 2014 stating that:

I want to thank you for your guidance, especially over the last twelve months. Without your insightful recommendations and your discreet and tactful intervention, Cambodia wouldn't have seen this end to the political crisis. However a historic challenge still lies ahead. To ensure the success of a difficult but necessary reform process in the key sectors you have addressed in your reports Cambodians from all political affiliations need your constant support and that of the United Nations. ${ }^{49}$

He also wrote to me on June 9, 2011 stating that he deeply appreciated my "continuous effort to promote democracy and defend human rights in Cambodia. The Khmer people are very lucky to have a friend like you." 50

Of course, there were periods of despair when the leader of the opposition was in exile in France due to politically motivated charges, a prominent human rights activist and director of an independent radio station was imprisoned, there were attempts to silence dissent from many quarters, including through assassinations, and I myself was subjected to orchestrated harassment. But I remained persistent, objective, independent, and impartial in the implementation of my mandate, which I continued to fulfill in a constructive manner and things began to take a turn for the better. I received the support of the international community and civil society organizations in the country. I was humbled by the overwhelming support I received, particularly from the youth, many human rights defenders, and the friends and well-wishers of Cambodia.

Owing to the endeavours of those fighting for human rights, including myself, the leader of the opposition was able to return to the country to

48 Press Release, Office of the U.N. High Comm'r for Human Rights, Cambodia: UN human rights expert hails political breakthrough, calls for promised reforms, U.N. HUM. RTS. OFF. HIGH COMM’R (July 22, 2014), http://www.ohchr.org/ EN/NewsEvents/Pages/DisplayNews.aspx?NewsID=14892\&LangID=E.

49 Letter from Sam Rainsy, President, Cambodia Nat'l Rescue Party, to author (Aug. 6 , 2014) (on file with author).

50 Letter from Sam Rainsy, President, Cambodia Nat'l Rescue Party, to author (June 9, 2011) (on file with author). 
participate in the political process following a royal pardon, ${ }^{51}$ a number of leading human rights defenders were released from prison, and the Government returned to a normal mode of cooperation with my mandate. After a year of protesting against alleged electoral irregularities, opposition party members joined the National Assembly, and the Government accepted the rationale for electoral reform contained in my reports. Accordingly, on October 1, 2014, the National Assembly passed a bill turning the National Election Committee into a constitutional body and implementing one of my key and long-standing recommendations. ${ }^{52}$

With regard to judicial reform, three long overdue fundamental laws were enacted in the autumn of 2014. They were the "Law on the Status of Judges and Prosecutors," the "Law on the Organization and Functioning of the Courts," and the "Law on the Organization and Functioning of the Supreme Council of Magistracy." Although these laws are by no means perfect, I believe that they provide a framework for improvement in the future. Therefore, I welcomed the enactment of these three laws, but pointed out the lack of consultation with civil society and transparency in the process of enacting these laws. ${ }^{53}$

Regarding land reform, one of the first concerns I expressed to the Government was the absence of an adequate package of compensation or resettlement policy for the people evicted from land. Soon after my first mission to the country, I was told that the Government had put in place a package of compensation for the people evicted from their land. Although the amount of compensation was still very small, nonetheless, this was a positive step in the right direction. One of the ideas that I championed and which was supported by the UN Human Rights Council was to encour-

51 Royal Decree No.NS/RKT/0713/827, July 12, 2013 (Cambodia).

52 Hul Reaksmey, Lawmakers Enshrine Election Panel in Constitution, CAмвоDia DAILy (Oct. 2, 2014), https://www.cambodiadaily.com/archives/lawmakersenshrine-election-panel-in-constitution-68826. The bill table before parliament was sent to my office by the Secretary-General of the National Assembly on 22 August 2014.

53 Press Release, Office of the U.N. High Comm'r for Human Rights, Cambodia: Lack of Consultation on key laws sets worrying pattern for future legislation, warns UN expert, U.N. HUM. RTS. OFF. HIGH COMM'R (May 27, 2014), http://www. ohchr.org/EN/NewsEvents/Pages/DisplayNews.aspx?NewsID=14648\&LangID=E. 
age the Government to put in place national guidelines on evictions and resettlements and some sort of guidelines are now in place.

Similarly, when I called upon the Government to impose a moratorium on the granting of economic and other land concessions until there was a proper policy and legal framework to ensure that such concessions did not undermine people's rights, the Government issued a decree in May 2012, during my visit to the country that focused on examining the human rights impact of economic land concessions, announcing a moratorium on new concessions, and pledging to review the existing concessions.

In August 2014, the Government decided to establish an inter-ministerial commission to examine, demarcate, and assess the economic land concessions already granted to private companies, whether foreign or national. ${ }^{54}$ By October 2014, the Government had cancelled eight of the economic land concessions. ${ }^{55}$

So far as freedom of expression is concerned, one of the foci of my oral statement delivered to the Human Rights Council on October 1, 2010 was on the need to decriminalise defamation and disinformation altogether in Cambodia. When the National Assembly adopted the new Penal Code later that month, there was no longer a prison sentence for defamation, even though the new Code had not gone far enough to meet the obligations of Cambodia under international law and practice. ${ }^{56}$

The work of my predecessors and myself, as well as of many national and international human rights organisations, had laid emphasis on the need to decriminalise defamation and disinformation. Addressing the $\mathrm{Hu}-$ man Rights Council in October 2009 I had expressed concern about the reported instances of lawsuits against the opposition party leaders brought by the Government and had requested further information about such cases. The Government responded to the communication by stating that they had taken such measures in compliance with the rule of law, implying reliance on the existing laws in the country.

However, the concern that I expressed was that the laws in question themselves fell short of the standards required by international human

\footnotetext{
54 Sub-Decree No. 245 ANK/BK, Sept. 9, 2014 (Cambodia).

55 Phak Seangly, Land concessions cancelled, Рнnom Penh Post (Oct. 17, 2014), http://www.phnompenhpost.com/national/land-concessions-cancelled. 
rights treaties and practice. In other words, in my view, the laws went beyond what is a permitted level of restriction on freedom of expression under the 1966 International Covenant on Civil and Political Rights. I went on to state that regardless of what the practice may be in any given country, whether a more established or less established democracy, the spirit of the provisions guaranteeing freedom of speech in international human rights treaties is to treat any matters relating to restrictions on such freedom, including defamation issues, under civil law rather than under criminal law, unless such matters are of a grave nature and thus, pose a threat to national security or public order in the country concerned.

I know there are a number of colleagues at Leeds Law School, including Professor Mullis, who are experts in this area, and they may have different views on this matter. But, what I was advocating in Cambodia was on the basis of international standards and the general comments issued by the UN Human Rights Committee on the provisions concerning freedom of speech in the 1966 Covenant on Civil and Political Rights.

Overall, when I concluded my mandate, things looked cautiously optimistic. It remains to be seen how sincerely and swiftly the promised reforms will be carried out in practice. There are a number of other serious human rights issues that remain unresolved. For instance, the list of impunity cases is long and growing. Little has been done to bring perpetrators to justice.

The peaceful transition now underway remains fragile. Many of the issues surrounding land rights remain unresolved, and the people on the margins of society continue to suffer from serious violations of their rights. However, without a doubt, the most significant change since July 2013 is that the Cambodian people have found their voice. It is my belief that Cambodia is on the cusp of historical change.

\section{b. Examples of Other Direct Impact}

I believe that my sustained efforts have brought about other tangible results for the people of Cambodia, including the release of a prominent journalist and human rights defender, Mr. Mam Sonando from prison in March 2013, better treatment to another leading journalist in a prison in the outskirts of Phnom Penh, and the return of the leader of the opposition party, Mr. Sam Rainsy, from his long exile in Paris in July 2013. Mr. Rainsy's return 
was allowed under a royal pardon that was made in time, allowing him to participate in the country's elections, which took place that year. ${ }^{57}$

I have also been credited for dissuading the Government of Cambodia from enacting a restrictive law on NGOs, ${ }^{58}$ persuading the Government to impose a moratorium on economic land concessions that have a detrimental impact on human rights, and encouraging the Government to enact a law on expropriation to provide compensation to people affected by land evictions. ${ }^{59}$

During my second mission to Cambodia in January 2010, I went to visit two journalists imprisoned on charges of defamation in the main prison, known as Central Correctional Centre 1 (CC1), in the outskirts of Phnom Penh. They were Mr. Hang Chakra and Mr. Ros Sokhet. When I met the Minister for Interior after the prison visit, I urged him to explore ways of releasing them from prison, arguing that in a democracy they would not be imprisoned for criticising the policies of the Government or of Government Ministers. Three months later, Mr. Hang Chakra was released from prison after being pardoned by the King of the country to mark the Khmer New Year in April 2010.

During my visit to the prison, I made a direct appeal to the prison Governor to improve the conditions under which these men were held in the prison. The day on which I completed my second mission to the country, the sister of Mr. Ros Sokhet published a letter in the main national daily newspaper of Cambodia, The Cambodia Daily, under the title "UN Envoy

57 Letter from Mam Sonado to author (on file with author); Letter from Sam Rainsy, President, Cambodia Nat'l Rescue Party, to author (on file with author); Letter from the editor of a main national daily English newspaper to author (on file with author).

58 Sen David \& Vincent Maclsaac, Government makes U-turn on NGO law, Phnom Penh Post (Oct. 28, 2011), http://www.phnompenhpost.com/national/ government-makes-u-turn-ngo-law.

59 Mark Tran, UN expert calls on Cambodia to amend draft NGO law, GUARDIAN (London) (Sept. 28, 2011), http://www.theguardian.com/global-development/2011/ sep/28/special-rapporteur-cambodia-draft-ngo-law; Mark Tran, UN urges Cambodia to hold companies to account over land disputes, GuARDIAN (London) (May 14, 2012), http://www.theguardian.com/global-development/2012/may/14/ un-cambodia-companies-land-disputes. 
should be praised for helping imprisoned journalist." ${ }^{60}$ Since the prison Governor had started to accord both of them much better treatment from the day I visited these journalists. ${ }^{61}$

\section{MY APPROACH TO IMPLEMENTING THE UN MANDATE}

Many people both within and outside of the UN have asked me what are the lessons that we can draw for the institution of UN Special Rapporteurs from my experience as the longest serving rapporteur for Cambodia. Therefore, without meaning to be self-publicising or self-aggrandising, I would like to, if I may, outline my own experience and the approach that I adopted in discharging my mandate. I believe the reason I was able to accomplish as much as I did in Cambodia and lasted in the UN mandate for the country as long as I did, i.e. full six years, and more than any of my predecessors was down to the following factors:

First, I took a constructive approach. In other words, I went beyond naming and shaming to offering suggestions. I saw it as more of a mandate to assist the Government with the management of transition rather than finger-pointing. It is not easy to go to a sovereign country and tell the leaders of that country what the shortcomings are in their system of governance. But this is the job of a Special Rapporteur for human rights. If the task of pointing out the shortcomings is coupled with friendly constructive recommendations one can keep them engaged in the dialogue.

Second, I carried out thorough fact-finding missions into the country, making sure that I could not be challenges on my factual accuracies. Third, as an international lawyer, I took a professional approach to the human rights problems facing Cambodia. I was principled and resolute in my approach, and I believe people across the board respected me for what I stood for. I maintained my objectivity, impartiality, and independence throughout my tenure. I tried to play the role of an international diplomat,

60 Ros Rada, UN Envoy Should be Praised for Helping Imprisoned Journalist, Cambodia Daily, Jan. 29, 2010, at 12.

61 Ted Piccone, Catalysts for Rights: The Unique Contribution of the UN's Independent Experts on Human Rights 15 (2010). 
a human rights activist, a human-rights law academic, and a government adviser - simultaneously.

Fourth, utilizing the flexibility of the UN mandate, I went on to define my own mandate and implemented it in the manner I thought it would be most effective. Fifth, rather than regarding myself solely as a human rights envoy focussed narrowly on thematic, technical, and mechanical aspects of human rights I took on the role of a political envoy as and when I deemed desirable to do so, expanding the scope of my work, and dealt with the totality of the political picture which had direct bearings on human rights. After all, we all know there is a very fine line between politics and human rights.

Sixth, I selected the areas for closer examination for which I thought I was most suited in terms of my expertise and background. I knew that the institution of Special Rapporteurs was a weak mechanism, but it was a mechanism which could show direction. Therefore, I chose the areas which I thought needed the most attention and at the same time the areas in which I could act most effectively.

Seventh, when making my case to reform State institutions that are responsible for upholding people's rights, I relied on a comparative analysis that I had carried out in a number of other developing countries from different continents with better and stronger democracies, such as Philippines, India, South Africa, Ghana, and Brazil. I knew that it would not go well in Cambodia if I said that the British or the French or the Americans did things in this way. I also drew on my own experience of work during my earlier career for the Royal Commission on Judicial Reform in Nepal, a country that is similar in so many respects to Cambodia.

Eighth, I sought to engage myself with the Government through conversations rather than isolate myself from the Government. I also maintained my diplomatic decorum and professionalism even when I came under unfair criticism and bias from the Government. So much so, even when I was harassed and intimidated by the Government in an effort to silence me, I did not give in to my temptation to retaliate against it in any manner. Nearly half way through my mandate, I did consider resigning in the face of hostile attitude from the Government, but decided to continue on. ${ }^{62}$ After all, I had a job to do and a mission to accomplish. In an article

62 Kevin Ponniah, Optimistic Subedi bids adieu to Cambodia, Рнnom Penh Post, Jan. 24, 2015, at 3. 
posted on the website of the Council of Ministers, Professor Pen Ngoeun, one of the many vocal critics of my work in Cambodia and also an advisor to the Government, commented on my determination to stay in the country and my persistence in having my recommendations implemented. ${ }^{63}$ He wrote, "[a] consummated diplomat [he] will not leave acrimony behind nor stain his swan song." ${ }^{34} \mathrm{He}$ added that I had "thick enough skin to withstand the attacks from all sides. Facing untenable situation many UN officials ... washed their hands and walked away, right or wrong who cares? Not Prof. Surya Subedi."65

Ninth, I established and maintained formal and informal diplomatic and political channels with the people in the Government to convey my concerns and to ask for information. They were willing to give information on most of the occasions. There were a number of occasions in which I wrote directly to the Prime Minister and he responded to my letters. On some occasions, the Ministers themselves would give me the information that needed to write my reports. For instance, on 2 June 2014, Senior Minister and Minister of Land Management, Urban Planning and Construction, Im Chhun Lim, wrote me detailed information concerning land and housing rights and economic and other land concessions.

Tenth, I was sensitive to the Asian notion of 'losing face.' I did my utmost to be respectful to the people in the Government and tried not to put them publicly in any awkward position. I was more candid in delivering my message to the Prime Minister in private than in public and maintained a balance so as not to deviate from diplomatic niceties in public. I was aware that every nation had its own pride, and I did my best to respect the pride of Cambodia with its rich ancient Hindu-Buddhist cultural heritage.

Eleventh, I was prepared to give credit to the people in the Government whenever it was due. This made them clamour for my praise, and remain engaged with me. This is because any praise that I would give could be used for publicity, often in an amplified form, aimed at the domestic audience. Twelfth, I always remained optimistic even in the midst of adversity and

63 Pen Ngoeun, Opinion, UN Special Rapporteur Surya P. Subedi, His moment to take final credit on his job, His swan song to Cambodians, Agence Kampuchea Presse (Jan. 16, 2015), http://www.akp.gov.kh/?p=56883.

64 Id.

65 Id. 
kept my hope alive for a constructive engagement of both the Government and the opposition party.

Thirteenth, I built a personal rapport with a number of key people in different walks of life in Cambodia, including the leaders of the opposition party, civil society organizations, and the media. By doing this, I made it harder for the Government to dismiss my recommendations or my services. Fourteenth, I made alliance with the foreign diplomatic community in Phnom Penh, so that they could help me deal with the Government. As a result, they stood by me in my difficult times.

Fifteenth, I chose soft diplomatic language to deliver difficult messages to the Government. On one of my reports, I said that the judiciary in Cambodia was not independent in the most diplomatic manner. In fact, the Prime Minister commented publicly that I was no different from my predecessors in delivering difficult messages, but went on to say that I was a pleasant enough man to talk to. He said I was 'an old whisky in a new bottle!' Commenting on the style of my reports, The Phnom Penh Post, which is an independent and critical English daily newspaper in Cambodia, made the following remarks: "At first sight, the report [my report to the $\mathrm{UN}$ ] may appear to give a positive outlook for the human rights situation in the country. But if you read it in between the lines, you will find one of the most powerful indictments of the Cambodian Government in years." 66

Sixteenth, I knew from the very beginning that the UN was an organization with its own imperfections, and the UN human rights machinery was chronically underfunded and understaffed. Therefore, I was one of those few UN Special Rapporteurs who never complained about any shortcomings in the level of support provided by the UN in discharging our responsibilities. I accepted the fact that once you volunteer for such a position, you have to commit your own private time needed to do the job to the best of your ability and mobilize any other resources at your disposal. Consequently, the UN staff and many assistants in Geneva and Phnom Penh rendered me a superb level of support throughout my mandate, which enabled me to perform my duties well.

Seventeenth, I maintained a good balance by taking a principled and pragmatic stand on various issues, and I believe this approach greatly helped me. Eighteenth, I was driven by my desire to make a tangible impact

66 Nicolas Agostini, Overcoming Cambodia Fatigue, Рнnom Penн Post (Sept. 30, 2014), http://www.phnompenhpost.com/overcoming-cambodia-fatigue. 
on the situation of human rights in Cambodia, and I had the same focus throughout my mandate. Other matters became secondary. My objective was not to make a point, but to make a difference, even if it was a small difference.

Nineteenth, while maintaining my dialogue with senior members in the Government, I made a lot of efforts to keep the leaders of the opposition party confident. The leader of the opposition party, Sam Rainsy, paid several visits to me in England during his exile in France to confide me about his views and concerns and also to ask for my help. Twentieth, I acted as a friend and as rallying point for human rights NGOs and other human rights defenders in our collective endeavour. I built a personal rapport with the leading human rights activists who became important allies to me in my dealings with the Government.

Twenty-first, I was always mindful of the fact that, as an independent Special Rapporteur, you have to pick up the pieces yourself from any fallouts from your reports. The UN has no mechanism to come to your rescue when governments become hostile. That was the fate of my predecessor, and I came close to facing that fate myself. The argument for non-action heard in the corridors of the UN buildings in Geneva is that if the UN intervenes in defence of an Special Rapporteur, then their impartiality could be questioned. The implication of this is that Special Rapporteurs should be left to their own devices.

Twenty-second, I made every effort to keep ambassadors from key countries informed so that they would know what was going on and support me when needed. After all, they were the decision makers within the UN Human Rights Council. I ended up making history within the UN system, which does not allow a renewal of the mandate of country-specific mandate holders for more than one year at a time, by having my mandate renewed twice for an unprecedented term of two years.

I knew I would come under sharp criticisms from the Government of Cambodia after releasing a report stating that the National Election Committee was not independent and sweeping electoral reforms were necessary. I thought the Government would make its utmost efforts to abolish or make it harder for me to continue my mandate. Therefore, I wanted to have my mandate protected for two years at a time, taking it beyond the reporting period. Thanks to the support of the ambassadors from key countries, the 
Human Rights Council renewed my mandate for two years in $2011 .{ }^{67}$ The Cambodia Daily, an independent and critical newspaper, had made the following remarks on the decision made by the Human Rights Council:

\begin{abstract}
The extension came only two days after the envoy, Surya Subedi, delivered a strongly worded report on the shortcomings of the National Assembly and urged the Government not to pass a controversial law on NGO ... deviating from the usual one-year renewal, though, the Council agreed to extend Mr. Subedi's term to allow the envoy to better plan his future moves and save itself the trouble of revisiting the issue a year from now. ${ }^{68}$
\end{abstract}

Once this precedent was established, it was not difficult for the Council to renew my mandate for another two years for the second time in 2013. This provided me stability and enabled me to be more strategic in my approach to the human rights challenges in the country and denied the country any chance of garnering enough political support within the UN Human Rights Council, a political body, to abolish the UN mandate in Cambodia.

As anticipated, the Government became hostile towards me after I released my report on electoral reform. I had a lot of explaining to do to the Government and all other stakeholders. Many ambassadors, especially the EU Ambassador to Cambodia, Jean-François Cautain, went out of their way in defending my work publicly. I was on the verge of being declared a persona-non-grata in Cambodia. If they had done so it would have done a lot of good to me since this status is regarded as a 'badge of honour' within UN human rights circles. But this would have meant that I would not have been able to work with the Government any more or have my recommendations implemented. My reports would have gone to the shelves gathering dust, as do many UN reports.

After receiving two badges of honour already from the monarchs of two countries - an $\mathrm{OBE}^{69}$ from Her Majesty the Queen of the UK and a

67 Human Rights Council Res. 18/25, U.N. Doc. A/HRC/RES/18/25, g 9 (Oct. 17, 2011).

68 Zsombor Peter, UN Envoy Gets New Two-Year Term Extension, Cambodia Daily, Oct. 3, 2011.

69 See International Lawyer Receives Award, ILA Newsletter (Int'l L. Ass'n, London), no. 22, 2005, at 10-12 (The full texts of the then British Foreign Secretary Mr. Jack Straw's speech and my OBE acceptance speech made at an investiture in London). 
$\mathrm{SGDB}^{70}$ from the King of Nepal for my services to international law - and after being known in international legal circles as an honorary Yorkshire man from god's own county (as I have spent much of my working life in Yorkshire) I did not need another 'badge of honour' in the form of a PNG (persona-non-grata)' from Cambodia!

\section{CONCLUSION}

The Cambodia mandate has turned out to be more challenging, demanding, and onerous than I had anticipated when I agreed to my appointment to this position. It is a very sensitive mandate and I had to walk a very narrow path in implementing my mandate. However, I have enjoyed the challenges and tried to strike a balance in my approach since I was fully aware that I had to maintain my impartiality, objectivity, and independence in my work so that I could be effective in this job.

The appointment has been a privilege and source of intellectual satisfaction for me. I have come to believe that the challenges thrown at me by the Cambodia mandate has certainly assisted in expanding my brain capacity and its agility. The head of the Cambodia office of the UN High Commissioner for Human Rights, Mr. Christophe Peschoux, had told me when I went on my first mission that as a human rights person there was not a single day which was dull in Cambodia. I came to realise how right he was!

Cambodia has come a long way from where it was six years ago. The country is currently in the process of peaceful political transition. Of course, it still has a long way to go in order for it to meet the international benchmark on human rights. A great deal of what has been achieved in Cambodia, such as the enactment of three fundamental laws to enhance the independence of the judiciary ${ }^{71}$ or the amendment of the Constitution to grant constitutional status to the National Election Committee, ${ }^{72}$ has been on paper. As the cliché goes, the proof of the pudding is in the eating. The progress in the country will depend on the implementation of

\footnotetext{
70 It is a high level state honour of Nepal.

71 Vong Sokheng, CPP passes judicial law in Senate, Рнnom Рenh Post (June 13, 2014), http://www.phnompenhpost.com/national/cpp-passes-judicial-laws-senate.

72 Constitution of the Kingdom of Cambodia, amend. Oct. 23, 2014, Ch. XV.
} 
these laws with the degree of sincerity required. Many of the reforms that I have highlighted will not improve the situation of human rights overnight within the country. The impact of these reforms will be felt in five or ten year's time. Many of the people in power in Cambodia are the people with a socialist mind-set and are thus resistance to change. Therefore, my successor, Professor Rhona Smith, who also happens to be a Professor of International Human Rights Law at another British university, will have an equally daunting task ahead of her, and I wish her all the best in this challenging position.

People often say that it depends on whether you see the glass half full or half empty. But I see the glass half full with water and the other half filled with air. In terms of the situation of human rights in Cambodia the water level in the glass is rising gradually and the tide has turned for the better. The Government, the opposition parties, the people, and the civil society organizations were striving to improve the situation of human rights in the country in order to move it forward; they needed international assistance to achieve their objectives. There, I came along to make my own contribution as a UN human rights expert and am thankful to all who have supported me in various ways to enable me to make this contribution at this juncture in Cambodian history.

I am thankful to my own institution, the University of Leeds for its support, without which it would have been great deal harder for me to do this job on behalf of the UN. Of course, there are direct and indirect benefits for the university from such work of its academics. As our Dean, Professor Jeremy Higham, keeps telling me that work of this nature does put Leeds on the wider map of the world and this is especially so in UN circles and in the world of human rights. In addition, my scholarly work has been informed by the experience gained through such engagements and I am of the view that scholarly work and policy making are mutually enriching, and this blend has been to the benefit of both my students and fellow scholars alike. Onerous external commitments of this nature take their own toll on your health, on the family and on the job at the University. I have a very considerate and supportive wife and understanding children, and I thank them for their support.

If you are an international law professor at a leading university such as Leeds, the world expects you to go out and about to make your own contribution to influence the development and implementation of international 
law at a global stage. I have been fortunate to have had a number of such opportunities to contribute to policy making at a very high level, whether it is as a UN Special Rapporteur or as an advisor on human rights to the British Foreign Secretary or as a delegate of Nepal to the UN General Assembly or now as an advisor to the World Economic Forum in Davos. In the course of my career I have consistently decided to roll up my sleeves and tried to put my ideas into action and drive myself as hard as I can for good causes - the promotion of rule of law, democracy, and human rights. 